\title{
Review of the Optimal Design on a Hybrid Renewable Energy System
}

\author{
Yuan-Kang $\mathrm{Wu}^{1, \mathrm{a}}$ and Shih-Ming Chang ${ }^{1}$ \\ ${ }^{1}$ Department of Electrical Engineering, National Chung-Cheng University, 62102 Chiayi, Taiwan
}

\begin{abstract}
Hybrid renewable energy systems, combining various kinds of technologies, have shown relatively high capabilities to solve reliability problems and have reduced cost challenges. The use of hybrid electricity generation/storage technologies is reasonable to overcome related shortcomings. While the hybrid renewable energy system is attractive, its design, specifically the determination of the size of PV, wind, and diesel power generators and the size of energy storage system in each power station, is very challenging. Therefore, this paper will focus on the system planning and operation of hybrid generation systems, and several corresponding topics and papers by using intelligent computing methods will be reviewed. They include typical case studies, modeling and system simulation, control and management, reliability and economic studies, and optimal design on a reliable hybrid generation system.
\end{abstract}

\section{Introduction}

The limited reserves of fuel oils and their unstable prices have significantly increased the interest in renewable energy sources. The alternative energy sources are non-polluting, free in their availability, and continuous. The motivation behind the use of renewable energy sources is the reduction of $\mathrm{CO}_{2}$ emissions. This is especially true in isolated, standalone, small islands where the access to renewable energy sources is the only solution to meet their energy needs. Today, wind and PV generators are utilized in such applications as water pumping, lighting, electrification of remote areas and telecommunications. For remote systems like radio telecommunication, satellite earth stations, or at sites that are far away from a conventional power system, the hybrid generation systems have been considered as preferred [1]. At present, standalone solar photovoltaic and wind systems have been promoted on a comparatively larger scale; however, these independent systems cannot provide continuous source of energy. Therefore, energy storage systems will be required for each of these systems in order to satisfy the power demands. Usually storage system is expensive and the size has to be reduced to a minimum possible for the renewable energy system to be cost effective. Hybrid power systems can be used to reduce energy storage requirements [2].

In the world, a significant number of villages may never be connected to the national grid due to their remoteness, or communities are far from the conventional electrical grid due to natural obstacles and environmental constraints. For the people living in these communities, access to renewable energy sources may be the only solution to meet their energy needs. Therefore, the design and operational

\footnotetext{
${ }^{\mathrm{a}}$ Corresponding author : allenwu@ccu.edu.tw
} 
experience of hybrid power systems for small micro grids are important. In order to meet sustained load demands during varying natural weather conditions, different renewable energy sources need to be integrated with each other. Therefore, dynamic modeling of various components in isolated systems and steady-state/transient simulation works are required. Furthermore, an overall control strategy for power management among different energy sources in a multisource energy system is needed. The controller should determine the online operation modes for each generation subsystems and switch from power regulation to maximum power conversion. Reliability evaluation and economic analysis are also very important in the planning of hybrid energy system for a particular site. In order to efficiently and economically utilize the renewable energy resources, one optimum sizing method considering system reliability and economical benefit for the hybrid generation system is necessary. The optimum sizing method can help to guarantee the lowest investment with full use of the PV array, wind turbine and energy storage system, so that the hybrid system can work at the optimum conditions in terms of investment and system reliability. Different sizing methods, such as probabilistic approach, iterative approach and artificial intelligence method, can be applied to reach a techno-economically optimum hybrid renewable energy system. Whichever sizing and optimization technique are used, they must ultimately search for an optimum combination of the system reliability and cost.

This paper will concentrate on reviewing significant research issues and current state about the hybrid renewable generation system. These topics include several typical case studies of renewablebased micro-grids, modelling and simulation for renewable energy systems, control and management of hybrid renewable energy systems, reliability and economic studies, and optimal design of a reliable hybrid generation system. A number of intelligent computing methods have been utilized in these researches and most of them will be summarized in this paper.

\section{Case Studies on Small-Scale Hybrid Generation Systems}

In the beginning of designing a small-scale hybrid generation system, the historical power consumption of load, load pattern, solar radiation values, and wind character have to be investigated. The availability of renewable energy resources is an important factor to develop the hybrid power system; that is, weather data are important factor for pre-feasibility study of renewable hybrid energy system for any particular site. For example, hourly solar radiation, clearness index, wind speed, and wind direction for several years should be collected so that the long-term average annual resource can be evaluated. Moreover, from the above given data, the probability functions of wind speed and solar radiation can be obtained. In [3], the design and sizing of hybrid power system for small base transceiver stations (BTS) in Indonesia are presented. Combination of wind and solar energy sources are used as the main source and utility line is used as a backup. The average wind speed in this area is about $4-5 \mathrm{~m} / \mathrm{s}$, and the average sunshine hour in this site is between 7 to 8 hours a day during the dry season and between 5 to 6 hours a day during the rainy season. The design of this hybrid generation system includes a $4.8 \mathrm{~kW} \mathrm{PV}$ array, $2.5 \mathrm{~kW}$ wind turbine, and $1200 \mathrm{Ah}$ battery. It will provide electricity to a BTS with an average power demand of $4 \mathrm{~kW}$. By using this hybrid power system, about 90 percent of the required power can be supplied by renewable energy sources. Paper [4] proposes the most feasible configuration of a stand alone PV/Wind Hybrid Energy System with diesel generator as a backup for cellular mobile telephony base station site in isolated areas of Central India. In this case, the power requirements for the GSM load are about $2 \mathrm{~kW}$ continuous, and the proposed hybrid system consists of two $7.5 \mathrm{~kW}$ horizontal-axes type wind turbines, a $5 \mathrm{~kW}$ Photovoltaic array, a $1 \mathrm{~kW}$ diesel generator, $1.83 \mathrm{kWh}$ battery bank and $2 \mathrm{kVA}$ Inverter. Paper [5] proposes a photovoltaic/wind based hybrid power system connected to a common bus with battery storage and conventional backup source to supply a $2 \mathrm{~kW}$ telecommunication load in Malaysia. The hybrid system consists of $4.5 \mathrm{~kW}$ PV system, $2 \mathrm{~kW}$ wind system, and $5 \mathrm{kWh}$ battery. Paper [6] also presents an innovative wind/PV/diesel hybrid system implemented in three remote islands in the Republic of Maldives. In this micro-grid system, twenty four $1.8 \mathrm{~kW}$ wind turbines are coupled to the micro-grid, and $2.5 \mathrm{kWp}$ of amorphous silicon PV modules are connected to AC grid through single phase grid connected inverter. This paper 
[6] undertakes renewable energy system planning using the software tool HOMER and to analyses the various options paying particular attention to the cost per unit of electricity consumed, fuel saved and initial capital requirements. In [7], a hybrid system of the pilot project in Lençóis Island located in the north area of Brazil is proposed. It composed of $21 \mathrm{~kW}$ solar PV power, $22.5 \mathrm{~kW}$ rated wind power, 120 batteries of 150Ah each, and a $53-\mathrm{kVA} / 48-\mathrm{kW}$ diesel generator as a backup unit. This paper also addressed the field operation results for this system, including power quality and reliability analyses. In [8], several types of projects developed in different small islands and remote villages were reviewed. Reference [9] analyzed the potential implementation of hybrid photovoltaic (PV)/wind turbine/diesel system in southern city of Malaysia, in which seven different system configurations were studied. Reference [10] also investigated the potential operation of hybrid energy system in the northernmost city in Africa. In which there were several system configurations with and without battery storage elements were studied.

\section{Modelling and Simulation of Renewable Energy Systems}

In order to meet sustained load demands during varying natural conditions, different renewable energy sources need to be integrated with each other. In addition, dynamic modeling of various components of this isolated system should be presented. Several papers have described dynamic modeling and simulation results of a renewable energy based hybrid power system. For example, in [11], a detailed dynamic model and simulation of a solar cell/wind turbine/fuel cell/ultracapacitor hybrid power system is developed. In [12], a PV/Wind hybrid electric power system interface with electric utility for solving modeling and simulation problems by using Matlab/Simulink environment have been proposed. Solar panels are the medium to convert solar power into the electrical power. A number of solar cell models have been developed, but the one diode electrical equivalent circuit is commonly used for cell based or module based analysis. The current source generates the photo-current that is a function of the incident solar cell radiation and temperature [13-14]. Wind turbines are used to convert the wind power into electric power. Based on Betz theory, the maximum converting efficiency of a wind generation system is $59 \%$. The developed wind power can be evaluated at a given wind speed through the power curve of the wind turbine. Power curves are usually provided by manufacturers of wind turbines. In terms of fuel cell, there are two typical types: low-temperature proton-exchange membrane FC (PEMFC) [15] and high-temperature solid oxide FC (SOFC) [16]. Both of them show great potential in hybrid energy system applications. The PEMFC model is an autonomous model operated under constant channel pressure with no control on the input fuel flow into the FC. The model was validated by experimental data measured from an Avista Labs SR-12 500 W PEMFC stack [15]. The FC will adjust the input fuel flow according to its load current to keep the channel pressure constant.

\section{Control and Management of Hybrid Renewable Energy Systems}

An overall control strategy for power management among different energy sources in a multisource energy system is needed. The objectives of the control and management of a hybrid energy system are to satisfy the changeable load power demand and to maintain the state of charge of the battery bank to prevent blackout and to extend the life of the batteries. For these purposes, the controller should determine the online operation modes for each generation subsystems and switch from power regulation to maximum power conversion. In [17], a comprehensive supervisor control for a hybrid system that comprises wind and photovoltaic generation subsystems, a battery bank, and an ac load is developed. Robust sliding-mode control laws have been considered in this paper to fulfill the different control objectives of the wind and solar subsystems. Paper [18] proposed an overall control strategy for a hybrid renewable energy system, in which the wind generation system is controlled by a pitch angle controller and a PV electricity generation unit is controlled by a maximum power point tracking (MPPT) controller; furthermore, dynamic models have been used for all the components of the system. At any given time, any excess wind and PV-generated power is supplied to the electrolyzer to generate 
hydrogen that is delivered to the hydrogen storage tanks. When there is a deficit in power generation, the fuel cell stack begins to produce energy for the load using hydrogen from the storage tanks. Paper [19] introduces the hardware realization of the energy management and control subsystem of a gridconnected wind/solar hybrid power system. The system is composed of several modules: programmable logic controller(FBs-40MAT from FATEK), AC multi-function electric power meters, Grid-connection control module, human-machine interface (HMI), dc electric power meters, and RS485/TCP converter to control and manage the operation of multi-source. Communication plays an important role in the system safe, reliable and precise operation for a hybrid renewable energy system. In [19], the communication protocol in the subsystem and between subsystems is Modbus RTU, while the communication with computer is implemented by RS485/TCP converters.

\section{Reliability Studies of Hybrid Renewable Generation Systems}

Reliability evaluation is very important in the planning of hybrid energy system for a particular site. The reliability is estimated in terms of the number of the critical load interruptions over a certain period of time; this choice is because the reliability of a system depends on the complexity of the system itself and not only on the number and the failure rates of its components. Typically, the reliability evaluation methods can be broadly classified into two types namely deterministic and probabilistic techniques[20]. Probabilistic techniques can be further classified into two types. They are analytical and Monte Carlo Simulation (MCS) methods. Several reliability indices are introduced in literature. Loss of Load Expected (LOLE), Loss of Energy Expected (LOEE) or Expected Energy not Supplied (EENS), Loss of Power Supply Probability (LPSP) and Equivalent Loss Factor (ELF) are some of the most common used indices in the reliability evaluation of generating systems. In general, the reliability assessment of hybrid generation system can be done by the following procedure:

- To collect required atmospheric data such as hourly solar radiation, hourly ambient temperature and hourly wind speed.

- To estimate hourly output power available from each type of source by using power generation models and considering outage schedules generated randomly using failure rates of units.

- To obtain total available generation with reliability index.

Reliability evaluation of PV/Wind hybrid energy system using well-being approach and Monte Carlo Simulation (MCS) method is discussed in [21], in which the "well-being" approach is implemented by combining deterministic and probabilistic approaches for applying to hybrid energy systems. Furthermore, the effects of different energy types, effects of changes in peak load and renewable capacity on system health and fuel savings are also studied in that paper. Paper[22] presented an evaluation model and applied it to analyze optimum generation expansion of small isolated systems using PV and wind energy sources. Paper [23] studied reliability and cost implications of PV and Wind Energy utilization in small isolated power systems. A Monte Carlo simulation approach has been utilized to incorporate the numerous random variables and their interactions. Paper [24] developed an analytical method for well-being assessment of small autonomous power systems having solar and wind energy systems.

\section{Optimal Design of a Reliable Renewable Energy System}

One of the most important issues in hybrid renewable systems is to optimally size the hybrid system components with possible minimum investment and operating costs. There are many studies about the optimization and sizing of hybrid renewable energy systems [25-29]. For example, References [25] reviewed different issues related to the modeling, analysis, optimal sizing, control and energy management strategies for hybrid system that are interconnected with wind power, solar photovoltaic and fuel cells. Reference [26] presented different sizing techniques and optimization techniques for off-grid PV-Wind hybrid systems. It also demonstrated that hybrid energy systems can significantly reduce the total life cycle cost of stand-alone power supplies and may constitute the most economical solution in many applications. Reference [27] designed and optimized (multi-objective optimization) 
the size of hybrid energy systems under smart grid theories that divide the load into high and low priorities. High priority load that should be supplied at any time but low priority load will be supplied only in case of the generation from wind/PV are greater than high priority load and the battery are full, otherwise this load can be shifted to next hour. Reference [28] applied the preference-inspired coevolutionary algorithm to the design of multi-objective hybrid renewable energy system. Three objectives, including the annualized cost of system, the loss of power supply probability and the fuel emissions, are minimized. Reference [29] modeled an optimal design of a PV/battery/micro-turbine hybrid energy system to supply power to remote communities by using genetic algorithm, in which the objective function minimizes the cost of energy production while covering the load demand with a specified value for the loss of load probability. Reference [30] designed techno-economically optimized systems by simulating behavior of various combinations of renewable energy systems with different sizing, including wind turbine (WT), photovoltaic (PV), fuel cell (FC), and battery banks.

\section{Conclusions}

The limited reserves of fuel oils and their unstable prices have significantly increased the interest in renewable energy sources. At a particular site, it is an important economical task for electrification of villages in rural areas or telecommunications. Therefore, the design of hybrid renewable power systems has received considerable attention in the last decade. In any hybrid generation system, sizing represents an important part of these system designs, including the optimal sizes of various renewable energy sources and storage systems. This paper has reviewed several typical case studies on hybrid renewable energy systems, including their modeling and simulation, control and management, reliability and economic studies, and the optimal size design by using intelligent computing methods.

\section{References}

1. C.H. Liu, K. T. Chau, and X.D. Zhang, "An Efficient Wind-Photovoltaic Hybrid Generation System Using Doubly Excited Permanent-Magnet Brushless Machine," IEEE Trans. on Industrial Electronics, vol.57, no.3, March 2010, pp.831-839

2. Francesco Bonanno, Alfio Consoli, Salvatore Lombardo and Angelo Raciti "A Logistical Model for Performance Evaluations of Hybrid Generation Systems," IEEE TRANS. on Industry Applications, vol.34, no.6, 1998, pp.1397-1403

3. P. A. Dahono, M. F. Salam, F. M. Falah, G. Yudha, Y. Marketatmo and S. Budiwibowo,"Design and Operational Experience of Powering Base Transceiver Station in Indonesia by Using a Hybrid Power System,"Telecommunications Energy Conference, Bandung, Bandung, Indonesia, 2009, pp.1-4.

4. P. Nema and S. Rangnekar,"Pre-feasibility study of PV-solar / wind hybrid energy system for GSM type mobile telephony base station in central India," Computer and Automation Engineering, Bhopal, India, 2010, pp.152-156.

5. D. B. Chia, B. L. Yong, R. K. Rajkumar, V. K. Ramachandaramurthy, "Design of a PV/Wind hybrid system for telecommunication load in Borneo region," Environment and Electrical Engineering, Malaysia, 2010, pp.73-76.

6. C. Nayar, M. Tang, W. Suponthana,"Wind/PV/Diesel Micro Grid System implemented in Remote Islands in the Republic of Maldives,"Sustainable Energy Technologies, Perth, WA, 2008, pp.1076-1080.

7. L. A. de Souza Ribeiro, O. R. Saavedra, S. L. de Lima, J. Gomes de Matos ,"Isolated Micro-Grids With Renewable Hybrid Generation: The Case of Lençóis Island,'IEEE Trans. on Sustainable Energe, vol. 2, no.1, January 2011,pp. 1-11.

8. Diana Neves, Carlos A. Silva and Stephen Connors, "Design and implementation of hybrid renewable energy systems on micro-communities: A review on case studies," Renewable and Sustainable Energy Reviews, vol. 31, 2014, pp.935-946. 
9. Mei Shan Ngan and Chee Wei Tan, "Assessment of economic viability for PV/wind/diesel hybrid energy system in southern Peninsular Malaysia," Renewable and Sustainable Energy Reviews, vol. 16, no. 1, 2012, pp.634-647

10. Taher Maatallah, Nahed Ghodhbane and Sassi Ben Nasrallah, "Assessment viability for hybrid energy system (PV/wind/diesel) with storage in the northernmost city in Africa, Bizerte, Tunisia," Renewable and Sustainable Energy Reviews, vol. 59, 2016, pp.1639-1652.

11. H. C. Chen, J. C. Qiu and C. H. Liu, "Dynamic Modeling and Simulation of Renewable Energy Based Hybrid Power Systems,"Electric Utility Deregulation and Restructuring and Power Technologies, Taichung, 2008, pp.2803-2809.

12. H. H. El-Tamaly and A. A. E. Mohammed, "Modeling and Simulation of Photovoltaic/Wind Hybrid Electric Power System Interconnected with Electrical Utility,"Power System Conference, Middle-East, 2008, pp. 645-649.

13. M. J. Khan and M. T. Iqbal, "Dynamic Modeling and Simulation of a Small Wind-Fuel Cell Hybrid Energy System,"Renewable Energy, vol. 30, no. 3, March 2005, pp.421-439.

14. S. Arul Daniel and N. Ammasai Gounden, "A Novel Hybrid Isolated Generating System Based on PV Fed Inverter-Assisted Wind-Driven Induction Generators,"IEEE Trans. on Energy Conversion, vol. 19, no. 2, June 2004, pp.416-422.

15. C. Wang, M. H. Nehrir, and S. R. Shaw, "Dynamic models and model validation for PEM fuel cells using electrical circuits," IEEE Trans. on Energy Conversion, vol. 20, no. 2, Jun. 2005, pp.442-451.

16. C. Wang and M. H. Nehrir, "A physically-based dynamic model for solid oxide fuel cells," IEEE Trans. on Energy Conversion, vol. 22, no. 4, Dec. 2007, pp. 887-897.

17. F. Valenciaga and P. F. Puleston, "Supervisor Control for a Stand-Alone Hybrid Generation System Using Wind and Photovoltaic Energy,"IEEE Trans. on Energy Conversion, vol. 20, no. 2, June 2005, pp.398-405.

18. C. Wang and M. H. Nehrir,"Power management of a stand-alone wind/photovoltaic/fuel cell energy system," IEEE Trans. on Energy Conversion, vol. 23, no. 3, September 2008, pp. 957-967.

19. G. LI , Y. Chen and T. LI , "The Realization of Control Subsystem in the Energy Management of Wind/Solar Hybrid Power System," Power Electronics Systems and Applications, China, May 2009, pp.1-4.

20. Billinton. R and R. Allan, Reliability evaluation of power systems, $2^{\text {nd }}$ Edition, Plenum Press, New York, 1996.

21. L. N. Kishore and E. Fernandez, "Reliability Well-Being Assessment of PV-Wind Hybrid System Using Monte Carlo Simulation,” Roorkee, India, March 2011, pp.63-68.

22. R. Billinton and R. Karki, "Capacity expansion of small isolated power systems using PV and wind energy," IEEE Trans. on Power Systems, vol. 16, no. 4, Nov 2001, pp.892-897.

23. R. Karki and R. Billinton, "Reliability/cost implications of PV and wind energy utilization in small isolated power systems," IEEE Trans. on Energy Conversion, vol. 16, no. 4, Dec 2001, pp.368-373.

24. D. K. Khatod, V. Pant and J. Sharma, "Analytical Approach for Well-Being Assessment of Small Autonomous Power Systems With Solar and Wind Energy Sources," IEEE Trans. on Energy Conversion, vol. 25, no. 2, June 2010, pp.535-545.

25. O. Erdinc and M. Uzunoglu, "Optimum design of hybrid renewable energy systems: Overview of different approaches," Renewable and Sustainable Energy Reviews, vol. 16, no. 3, April 2012, pp.1412-1425.

26. Ahmed Said Al Busaidi, Hussein A Kazem, Abdullah H Al-Badi and Mohammad Farooq Khan, "A review of optimum sizing of hybrid PV-Wind renewable energy systems in oman," Renewable and Sustainable Energy Reviews, vol. 53, 2016, pp.185-193.

27. Ali M. Eltamaly, Mohamed A. Mohamed and Abdulrahman I. Alolah, "A novel smart grid theory for optimal sizing of hybrid renewable energy systems," Solar Energy, vol. 124, 2016, pp.26-38. 
28. Zhichao Shi, Rui Wang and Tao Zhang, "Multi-objective optimal design of hybrid renewable energy systems using preference-inspired coevolutionary approach," Solar Energy, vol. 118, 2015, pp.96-106.

29. M.S. Ismail, M. Moghavvemi and T.M.I. Mahlia, "Genetic algorithm based optimization on modeling and design of hybrid renewable energy systems," Energy Conversion and Management, vol. 85, 2014, pp.120-130.

30. Hosseinalizadeh Ramin, Shakouri, Hamed G. Amalnick and Mohsen Sadegh, "Economic sizing of a hybrid (PV-WT-FC) renewable energy system (HRES) for stand-alone usages by an optimization-simulation model: Case study of Iran," Renewable and Sustainable Energy Reviews, vol. 54, 2016, pp.139-150. 